\title{
オホーツク海沿岸域からモンゴル 高原まで
}

\section{朝日田 康 司}

\section{1. なぜオホーツク海沿岸域か}

ソ連邦が崩れたことと冷戦構造の壞滅に よって、環日本海経済圈構想とか、環日本海 地域交流といった言葉がいわれるようになっ た。日本海に面する地域が国境をこえて交流 しようというものである。

北海道においても、道東道北地域でイン ターリジョナルな問題意識にもとづいた活動 が進められた。1990年（平成 2 年）12月、才 ホーツク海沿岸域に位置する 5 大学、すなわ ち、北見工業大学、東京農業大学網走キャン パス校の生物産業学部、道都大学（紋別市）、 北海学園北見大学、北海学園北見短期大学の 有志が結集し、オホーツク・大学間交流協議 会を発足させた。オホーツク地域に関する諸 問題について、専門分野をこえたボーダレス な交流を図り、地域の人びとと手をたずさえ て21世紀のオホーツクを創っていこうという のが主意である。

北海道は、太平洋、日本海、オホーツク海 の3つの海に囲まれている。環太平洋という 言葉は、環日本海よりも早くから使われてい るが、環オホーツク海圈については、人類学 や言語学といった特有の分野でしか注目され てなかった。この地域とかかわりのあるロシ ア (旧ソ連邦) や中国東北部にとって、この 地域は辺境の地であり、人口も少ないことな どにより、経済活動の対象になりえなかった からであろう。

しかし、オホーツク海沿岸域は、資源、環 境といった世界的・今日的視点からみると、

「環境と調和した成長」の可能性を秘めてお ク、新しい開発のあり方を示すモデルとなる
べき地域であり、日本における最後のフロン ティアなのである。そこで、北海道地区会議 は、第15期半ばにいたり、広大な北海道の中 から対象をこの地域にしばり新しい情報発信 基地の形成に寄与することとし、オホーツ ク・大学間交流協議会と交流することとした。

\section{2.日本学術会議北海道地区会議とオホーツ} ク・大学間交流協議会との交流

オホーツク・大学間交流協議会の会員は約 100名で、公開交流セミナ一、講演会等の開催 に加えてプロジェクト・チームによる共同研 究・共同開発等の活動を行っている。

北海道地区会議は、第 15 期の平成 5 年に、 この協議会の活動を支援し、「地域おこし新時 代」を共催して以来、毎年秋に共催の形をとっ てきている。開催地は各大学の所在地の北見 市、網走市、紋別市で輪番となっている。別 表に、年度別の実績を示しておく。

平成 6 年のフォーラム「各国の地域活性化 事例とオホーツク圈のとり組み」では、ノー ルウェイ、中国、カ十ダ、ドイツからの科学 者を招き、地域揖こし、環境づくりのテーマ で話しあわれた。

平成 7 年 3 月、学術の成果を生かした内外 地域間交流事業として開催したフォーラム

朝日田康司（南さひだやすし 1931年生）

日本学術会議第 6 部会員、第 $15 \cdot 16$ 期北海道地区会 議代表幹事、地域農学研究連絡委員会委員長、東京 農業大学生物資源開発研究所客員教授、北海道大学 名誉教授、中国・新疆農業大学名誉教授、同黒龍江 省畜牧研究所名誉研究員、同浙江農業大学客員教 授、農学博士

専門：畜産学、地域農学 
別表 日本学術会議第15及16期にオホーツク・大学間交流協議会と共催したフォーラム等一覧

北海道地区会議

\begin{tabular}{|c|c|c|c|}
\hline 期 & 年 月 日 & フォーラム等 & 開催場所 \\
\hline \multirow[t]{2}{*}{$\left.\begin{array}{c}\text { 第 } 15 \text { 期 } \\
(\text { 平成 } 3.7 .22 \\
6.7 .21\end{array}\right)$} & 平成 5.11 .27 & $\begin{array}{l}\text { 公開交流セミナー } \\
\lceil\text { ボーダーレス・オホーツク」 } \\
\text { 基調講演 } \\
\text { パネル討議 }\end{array}$ & 北見市民会館 \\
\hline & 6.2 .22 & $\begin{array}{l}\text { 学術連絡会議 } \\
\text { 「地域活性化に関する今後のあり方」 } \\
\text { (地域学力向上のためのふるさと学会開 } \\
\text { 催事業) }\end{array}$ & 北見市ピックアークホテル \\
\hline \multirow[t]{4}{*}{$\left.\begin{array}{c}\text { 第 } 16 \text { 期 } \\
\text { 平成 } 6.7 .22 \\
j \\
9.7 .21\end{array}\right)$} & 6.10 .29 & $\begin{array}{l}\text { 北方圈地域交流フォーラム } \\
\text { 「各国の地域活性化事例とオホーツク圈 } \\
\text { のとり組み」 }\end{array}$ & 北見市民会館 \\
\hline & 7.3 .3 & $\begin{array}{l}\text { フォーラム「環オホーツク海圈の将来」 } \\
\text { 地域交流研究会 } \\
\text { 基調講演 } \\
\text { パネル討議 } \\
\text { (学術の成果を生かした内外地域間交流 } \\
\text { モデル事業) }\end{array}$ & 網走セントラルホテル \\
\hline & 7.10 .27 & $\begin{array}{l}\text { 国際シンポジウム「北東アジア・環オホー } \\
\text { ツク海圈交流と拠点都市」 } \\
\quad \text { パネル討議 }\end{array}$ & 網走セントラルホテル \\
\hline & 8.10 .25 & $\begin{array}{l}\text { 公開交流セミナー「21世紀オホーツクを } \\
\text { 生きる」 } \\
\text { 基調講演 } \\
\text { パネル討議 }\end{array}$ & 紋別市民会館 \\
\hline
\end{tabular}

このほか、地区会議主催の講演会、科学者㤅談会を、毎年 $3 \sim 4$ 回全道各地で開催している。

「オホーツク海圏の将来」は特筆に值する。こ れは前年に学術連絡会議で準備した。

フォーラムのため、内外の地域間交流モデ 儿事業運営委員会 (委員長：筆者)を組織し、 この中に地域間交流研究会を設け調査研究を 行った。この一環として、筆者と七戸長生・ 北海道大学名誉教授が、厳冬 2 月に、中国東 北部・黒龍江省対外科学技術交流中心を訪問 した。そして北海道と黒龍江省の学・産・官・ 民が一体となって、両国が互いに北フロン ティアの朋友としてさらに交流していくこと を確認したのであった（これより先に、筆者 らは1982年（昭57年）から北海道黒龍江省科 学技術交流協会を組織し活動していたことも この調查研究を成功させた)。
フォーラムでは交流研究会の研究結果をふ まえて、環オホーツク海圈における内外地域 間交流のあり方を、地域住民とともに考えた のである。道外から九州・沖縄地区会議代表 幹事 (代理・荒木会員)、中山第 2 部長等も参 加された。この年は、2月 8 日に九州・沖縄 地区会議主催のフォーラム「有明の海と人」 に筆者もパネラーとして参加させていただ き、北海道地区会議の活動等について報告し た。

これを機に、日本列島の両端に位置してい る南北それぞれの海域の両地域は、今後の日 本のキー・エリアであるとの共通認識をとる に至った。共通及び独自の課題に関して両地 区会議が交流を四っていくことに、原則的に 
同意しているところであり、筆者は本年（平 成 9 年) 2 月、九州・沖縄地区会議にオブザー バーの資格で参加し、情報交換をした。平成 9 年度もそのような計画をもっている。

平成 7 年の国際シンポジウム「北東アジア における環オホーツク海圈交流の課題」では、 中国、モンゴル国、ロシア・サハリン州から の代表を加え、筆者も話題提供者となった。 筆者は、中国及び韓国との学術交流の経験、 及び平成 7 年 6 月の北欧 4 か国訪問時に目に した「環バルト海域協力プロジェクト」を参 考に、今後の課題をあげた。

筆者は過去15年間に、種々の研究班を組織 して、中国黒龍江省、内モンゴル自治区、新 疆ウイグル自治区の牧業の実態調査に従事 し、現地の大学・研究所との共同研究を行っ てきた。

オホーツク海を象徵的にあらわす言葉に冬 の流氷がある。その流水は黒龍江（アムール 河）河口でつくられる。黒龍江は、その源流 をゴビ砂漠の北の地モンゴル高原東部にも つ。流水のふるさとモンゴル高原は、筆者の 専門分野から、いつかは訪問したい地域で あった。

そんな中で、ついに本年 9 月、筆者はモン ゴル国訪問の夢を果たした。オホーツク・大 学間交流協議会のチャーター・メンバーであ る東京農業大学が、その姉妹校たるモンゴル 国立農業大学との学術交流を四るためプロ ジェクト研究調查団 (団長：臼井・生物資源 開発研究所長）を派遣することになり、筆者 も団員 8 名の中のひとりになった。僅か10日 間の滞在であったが、自然生態系とバランス を保ちながら草原を持続的に利用して牧畜生 産を行うという伝統的な遊牧のモンゴル高原 での実態に接し得た。このほかモンゴル農業
大学を会場に開かれたシンポジウムにも参加 した。テーマは寒地農業の開発と振興であり、 筆者は若干の提言をし、あわせて日本学術会 議の現状を紹介した。

以上のようなかたちで、北海道地区会議は、 流氷のまち道東道北からモンゴル高原まで、 地域における学術の振興にささやかながら貢 献できたと思っている。

本年 (平成 9 年) 度の公開交流セミナ一(筆 者は実行副委員長代理) には、東京農業大学 の招聘により、モンゴル農業大学から 2 名の 教授が参加することになっている。この稿が 「学術の動向」誌に載る頃は盛会裡に終ってい ることだろう。

\section{3. 今後の地区会議は?}

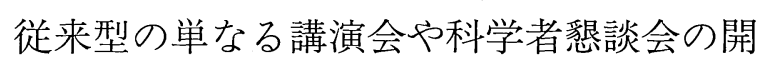
催だけでは、日本学術会議と全科学者の距離 が縮まるとは思われないという批判が寄せら れている(北海道地区ニュース、No.27、平成 7 年 3 月)。地域の科学者と日本学術会議とが ほとんど分断された状況にあることは覆うべ くもない。

第15・16期地区会議代表幹事として、日本 学術会議に、地方活動の充実・強化というス タンスがみえてこないことに苛立ちを覚えた ことは 2 度や 3 度ではない。しかしながら「地 域社会の学術振興に寄与する」という地区会 議が、北海道においては、僅か $3 \sim 4$ 名の会 員構成でありながら、第 $15 \cdot 16$ 期にはオホー ツク・大学間交流協議との交流を通して、地 域の広域文化圏の形成にかかわりあい、地域 の新たな風土創出に新風を吹きこんだと自負 している。

第17期以降も、北海道地区会議は、それな クに健闘していくであろう。 